\title{
Experimental arthritis in rats induced by intra-articular injection of IgE aggregates: evidence for arthritogenic role of complexed $\operatorname{IgE}$
}

\author{
L S de Clerck, N J Struyf, C H Bridts, E A van Marck, F C Breedveld, E Devries,
} H Bazin, W J Stevens saline solution contained $50 \mu \mathrm{g} / \mathrm{ml}$ gentamicin and $30 \mathrm{U} / \mathrm{ml}$ nystatin (Gibco, Paisley, UK).

An experimental arthritis model in the rat was used to study the arthritogenic potential of complexed IgE. IgE aggregates were produced in vitro by cross linking monoclonal rat IgE by dimethyl suberimidate and were injected into the knee joints. Animals which had not been injected and animals injected with phosphate buffered saline served as controls. The concentration of histamine in tissues, diffusion into the joint of bovine serum albumin labelled with iodine-125 injected intravenously, and the histology of the joints were studied. There was a significant decrease in the concentration of histamine in synovial tissue 8 and 24 hours after the injection of the IgE aggregates. A decreased number of stainable mast cells were found 8, 24, and 48 hours after exposure. A moderate hyperplasia of the synovial lining layer was also noted. These results provide further evidence for the arthritogenic potential of complexed IgE, especially in the initiation of arthritis through activation of mast cells.

It has been shown that immune complexes containing IgE are often found in patients with rheumatoid arthritis, especially those with severe arthritis with or without vasculitis. ${ }^{1-4}$ We have also shown that these complexes are locally formed or trapped in synovial fluid ${ }^{5}$ and that complexes containing IgE isolated from synovial fluid can activate inflammatory cells. ${ }^{6}$

In this study, further evidence for the arthritogenic potential of these complexes was provided using an experimental arthritis model in rats.

\section{Materials and methods}

PREPARATION OF IgE AGGREGATES

Monoclonal rat IgE (IR2) was isolated and purified from ascites of rats bearing immunocytomas as described previously. ${ }^{7}$ Covalent cross linking was performed according to Segal et al. ${ }^{8}$ Briefly, $\operatorname{IgE}(26.5 \mathrm{mg} / \mathrm{ml})$ was incubated for two hours at $30^{\circ} \mathrm{C}$ with a 30 fold molar excess $(114 \mu \mathrm{g})$ of dimethyl suberimidate (Pierce Chemical, Rockford, IL, USA) in $0.2 \mathrm{~mol} / \mathrm{l}$ TRIS hydrochloric acid, $\mathrm{pH} 8.5$. Oligomers were precipitated with a final concentration of $15 \%$ polyethylene glycol 6000 and redissolved to $20 \mathrm{mg} / \mathrm{ml}$ in phosphate buffered

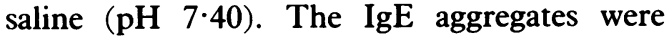
mainly dimeric, as shown by native polyacrylamide gel electrophoresis and by fractionation on a Sephacryl S-400 column (Pharmacia, Brussels, Belgium). The phosphate buffered

\section{EXPERIMENTAL RATS AND INDUCTION OF} ARTHRITIS

Outbred female Sprague-Dawley rats (Janssen Pharmaceutica, Beerse, Belgium) weighing approximately $250 \mathrm{~g}$ were anaesthetised with diethylether. Their hind legs were shaved and prepared using routine aseptic techniques. Two animals for each test received an intra-articular injection in two hind knees, obliquely through the patello-tibial ligament with a 25 gauge hypodermic needle. The following solutions were injected: $100 \mu \mathrm{g}$ IgE aggregate diluted in $500 \mu \mathrm{l}$ phosphate buffered saline solution (PBS), $1 \mu \mathrm{g}$ IgE aggregate in $500 \mu \mathrm{l} \mathrm{PBS}$, or $500 \mu \mathrm{l}$ PBS only. The PBS solution contained $50 \mu \mathrm{g} / \mathrm{ml}$ gentamicin and $30 \mathrm{U} / \mathrm{ml}$ nystatin. Two additional rats for each test received no intraarticular injection.

DETERMINATION OF HISTAMINE CONCENTRATION IN TISSUES

The concentration of histamine in tissues was determined in the infrapatellar fat pads 1,8 , and 24 hours after intra-articular injection of the test solutions or in uninjected control rats. The rats were killed by ether overdose. The infrapatellar tissue was removed as described previously. ${ }^{9}$ The fat pads were immediately weighed, frozen, and stored in glass tubes at $-20^{\circ} \mathrm{C}$ until assayed. After thawing, the tissues were frozen and thawed in $1 \mathrm{ml}$ of distilled water twice more. The histamine concentration was determined in duplicate in $200 \mu$ l of supernatant with the Pharmacia histamine RIA 50 test. This commercial test uses histamine labelled with iodine-125 and a monoclonal mouse antibody to histamine. The results are expressed as nanograms of histamine per milligram of dry tissue weight.

DETERMINATION OF PERMEABILITY RESPONSE The permeability of the synovial membrane was assessed using bovine serum albumin labelled with iodine-125 (NEN Research Products, Du Pont de Nemours, Brussels, Belgium), one and eight hours after intra-articular injection of the test solutions. Bovine serum albumin labelled with iodine-125 (111-185 kBq) and diluted in $500 \mu \mathrm{l}$ phosphate buffered saline was injected into the tail vein 30 minutes before killing the rats. The infrapatellar fat pads were removed, weighed and the radioactivity determined in a 
gamma counter (Auto-gamma Scintillation Spectrometer, Packard Instruments, Downers Grove, IL, USA). The results were expressed as the ratio of the counts per milligram of dry tissue weight over the counts per $100 \mu \mathrm{l}$ of corresponding plasma, to correct for differences in the dose of bovine serum albumin labelled with iodine-125 injected.

COLLECTION AND PREPARATION OF JOINT TISSUES FOR HISTOPATHOLOGICAL EVALUATION

The rats were killed 8,24 or 48 hours after intra-articular injection.

\section{Light microscopy}

For light microscopy the knee joints were collected at the same time by transverse section of the distal femur and the proximal tibia and fibula. The joints were trimmed of excess muscle and fixed in $10 \%$ neutral phosphate buffered formalin solution for one day. The joints were then decalcified for five days with a $10 \%$ formic acid-formalin solution. Subsequently, 3-4 mm gross sections were cut in a sagittal plane, dehydrated by graduated alcohols, embedded in paraffin and sectioned at $5 \mu \mathrm{m}$. All histological sections were stained with haematoxylin and eosin, Masson's trichrome stain, and giemsa. Inflammatory changes were scored blindly. The following parameters were assessed: presence of polymorphonuclear cells with or without fibrin in the joint space; synovial lining layer proliferation; subsynovial infiltration with polymorphonuclear cells; oedema of the vascular wall with or without necrosis; number of mast cells, scored as the number of stainable mast cells for each of four fields along the synovial lining layer at a magnification of 125 .

\section{Immunofluorescence}

The infrapatellar fat pad was examined to determine the immunofluorescence. Tissue was removed, immersed in Tissue-Tek (Miles Scientific, Naperville, IL, USA), frozen in liquid nitrogen and then stored for up to three weeks at $-70^{\circ} \mathrm{C}$ until sectioned. Transverse

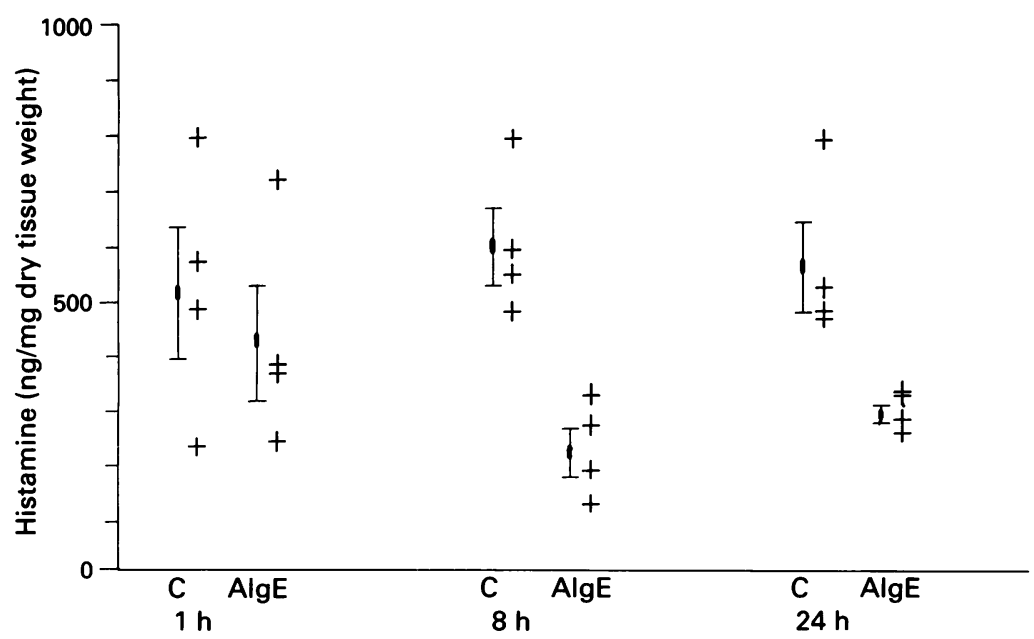

Figure 1 Histamine concentration (nanograms per milligram of dry tissue weight; mean $(S E M))$ in infrapatellar fat pad tissne of control rats $(C)$ and rats injected with 100 or $1 \mathrm{\mu g}$ of IgE aggregate $(A \lg E)$ at 1,8 , and 24 hours after injection. $n=4$ at each time point. sections $8-10 \mu \mathrm{m}$ thick were cut at $-20^{\circ} \mathrm{C}$ in a cryostat, picked up on glass slides, immersed in ice cold acetone for a few seconds and then air dried at room temperature. Before staining, the slides were stored at $-70^{\circ} \mathrm{C}$ for up to one week.

For staining with fluorescein isothiocyanate conjugated antisera the tissue sections were warmed to room temperature, rinsed with phosphate buffered saline and incubated for 30 minutes at $37^{\circ} \mathrm{C}$ with $50 \mu \mathrm{l}$ of rabbit anti-rat fibrinogen (Janssen Biochimica, Beerse, Belgium), then diluted 1 to 50 in phosphate buffered saline containing $0.5 \%$ bovine serum albumin and $0.5 \%$ Tween 20 (PBT). After rinsing in phosphate buffered saline, the slides were incubated for 30 minutes at room temperature with $50 \mu \mathrm{l}$ of fluorescein labelled swine anti-rabbit antibodies (Dakopatts, Glostrup, Denmark), diluted 1 to 80 in PBT. Finally, the slides were rinsed with phosphate buffered saline, incubated for 20 minutes at room temperature with a stabiliser (Amersham, UK) and allowed to dry. Mountant (Amersham) and a coverslip were applied. For the detection of $\mathrm{IgE}$, the tissue sections were incubated with $50 \mu \mathrm{l}$ of fluorescein labelled goat anti-rat IgE (Nordic Immunology, Tiburg, The Netherlands), diluted 1 to 50 in PBT. They were stabilised and covered as for the fibrin assay. The sections were examined with a Leitz Ortholux II fluorescence microscope.

\section{STATISTICAL ANALYSIS}

The results for the rats which had not been injected and rats injected with phosphate buffered saline were compared. As there was no clear difference between these groups, the results were pooled to one control group for the final analysis. The same procedure was followed for the groups injected with 100 and $1 \mu \mathrm{g}$ of IgE aggregate as the results for these two groups were also comparable. Statistical analysis was performed using non-parametric analysis of variance (Kruskal and Wallis) for numerical values and the $\chi^{2}$ or Fisher's exact test for categorical data where appropriate. A p value of $<0.05$ was considered significant.

\section{Results}

HISTAMINE CONCENTRATION

Figure 1 shows that there was a significant difference in the histamine concentration between control rats (not injected and injected with phosphate buffered saline) and the rats injected with $\operatorname{IgE}$ aggregates (100 or $1 \mu \mathrm{g}$ ) at 8 and 24 hours after intra-articular injection $(p=0.02)$, whereas there was no clear difference one hour after injection $(p=0 \cdot 06)$.

\section{PERMEABILITY RESPONSE}

No difference in the uptake of bovine serum albumin labelled with iodine-125 could be found between the knees of control rats and those injected with IgE aggregate $(p>0 \cdot 20)$.

\section{HISTOLOGY}

Mast cells

The most striking difference between the knees 
of control rats and rats injected with $\operatorname{IgE}$ aggregate was in the number of stainable mast cells. The mean (SEM) number of mast cells in control rats was $47(9)$ compared with $28(6)$ in the rats injected with IgE aggregate $(p<0.001)$. In the group injected with IgE aggregate, the mast cell numbers were lowest 24 hours after the injection of IgE aggregate; the mean (SEM) numbers of mast cells at 8,24 and 48 hours were 29 (5), 22 (3), and 31 (4), respectively.

\section{Synovial lining layer proliferation}

A synovial lining layer hyperplasia was noted in the knee joints of rats injected with IgE aggregate compared with the controls. The synovial lining layer was on average $3.6(1.0)$ cell layers thick in the group injected with IgE aggregate compared with $1.6(0 \cdot 7)$ in the control group $(p<0.001)$. Figure 2 shows that synovial lining layer hyperplasia could be observed eight hours after the injection of the IgE aggregates. No clear difference between the results obtained 8,24 and 48 hours after injection was found.

\section{Foint space}

Figure 2 shows that a scarce infiltration of polymorphonuclear cells could be found in the joint space of rats injected with aggregate, especially eight hours after injection. However, rare polymorphonuclear cells were occasionally found in a few rats injected with phosphate buffered saline. Small fibrin deposits in the joint space were found in two thirds of the rats injected with IgE aggregate, but could not be found in the control group $(p<0.01$, rats injected with aggregate versus controls)

\section{Subsynovium}

A definite subsynovial infiltration was not consistently encountered in the rats injected with IgE aggregate nor in the control rats. Occasionally, polymorphonuclear cells could be found in the subsynovium. The deposition of IgE could not be shown with the technique used. However, fibrin deposition could be detected by immunofluorescence in all the rats injected with IgE aggregate, whereas only one rat injected with phosphate buffered saline was positive $(\mathrm{p}<0.001$ aggregate injected rats versus controls)

\section{Vascular changes}

Half of the rats injected with IgE aggregate showed mild oedema of the vascular wall. This was not seen in the control group $(p<0.05$, rats injected with $\operatorname{IgE}$ aggregate versus controls). Vascular necrosis was not found in any of the rats.

\section{Discussion}

An IgE dependent mast cell mediated arthritis model has been described previously. ${ }^{10}$ In this model mast cell degranulation and transient synovitis were induced by an intra-articular injection of antigen specific IgE and parenteral challenge with specific antigen. This model, as well as other reports, ${ }^{1-13}$ suggests a possible role for IgE and mast cells in the initiation of arthritides. In addition several workers have focused on the possible role of mast cells in the pathophysiology of chronic inflammatory joint disorders in humans, especially in rheumatoid arthritis. ${ }^{14-18}$

Apart from monomeric IgE, there is a role for immune complexes containing IgE in rheumatoid arthritis, especially in severe arthritis and vasculitis. ${ }^{1-4}$ It could be speculated that activation through IgE containing immune complexes of mast cells and other inflammatory cells such as monocytes and macrophages, possessing IgE type II receptors, ${ }^{19}$ could play a role in the

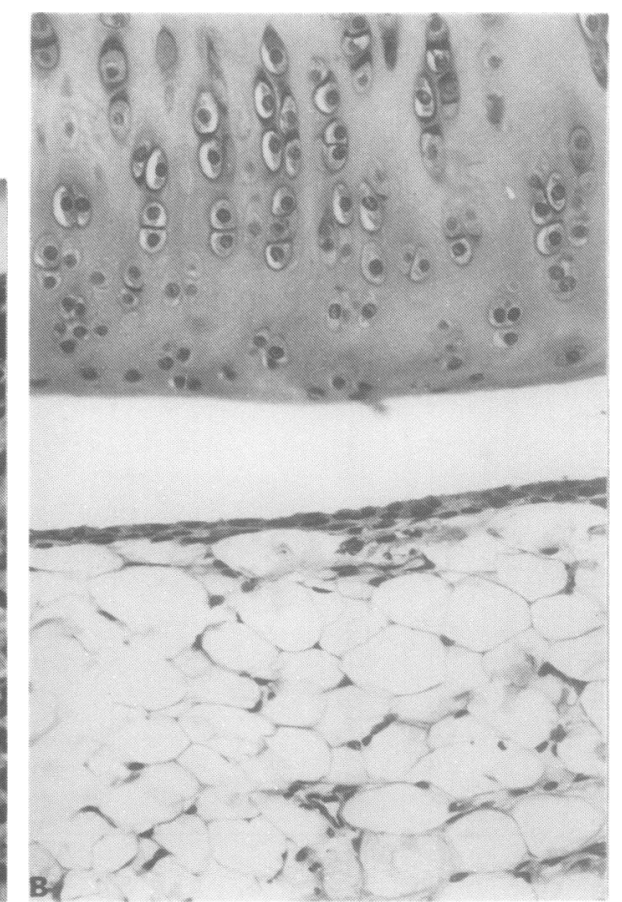

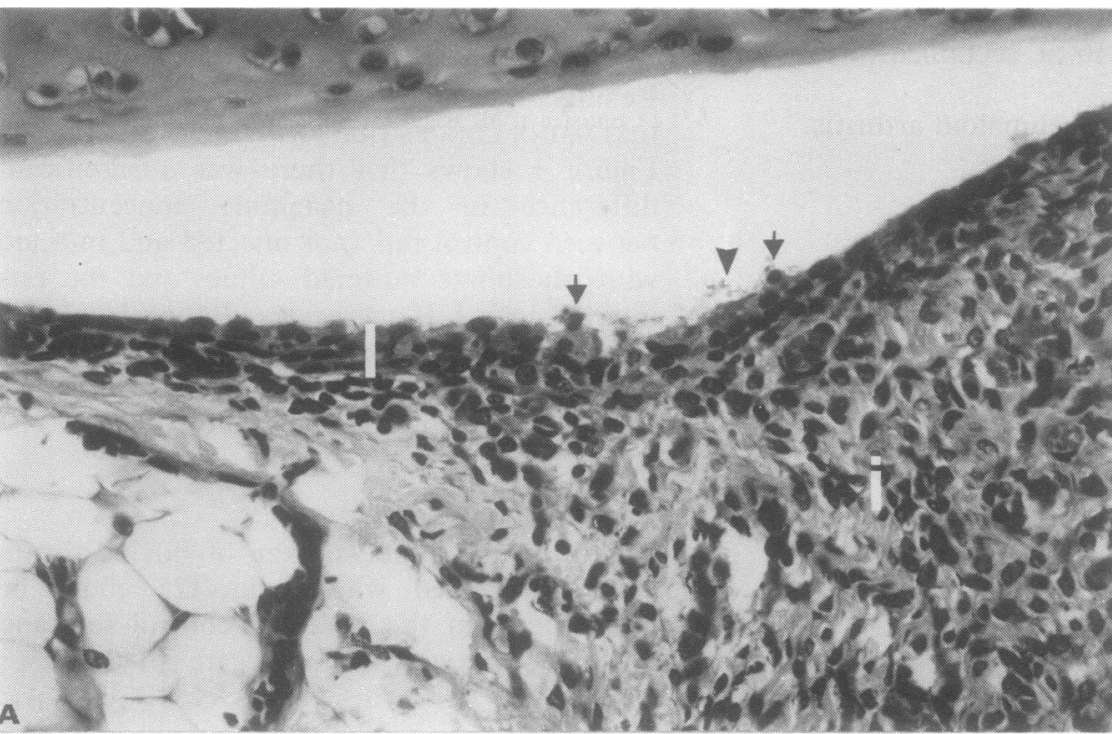

Figure 2 Photomicrograph of the sagittal knee joint section of a rat. (A) Eight hours after injection of IgE aggregates, showing synovial lining layer hyperplasia (I), inflammatory infiltrates (i) with rare polymorphonuclear leucocytes in the joint space (arrows) and synovium, and some fibrin deposition (arrowhead). (B) Eight hours after injection of phosphate buffered saline (control experiment). (Haematoxylin and eosin.) 
inflammatory events in rheumatoid synovitis and rheumatoid vasculitis.

To study the arthritogenic potential of complexed IgE further, we developed an experimental animal model in rats, using the intraarticular injection of aggregated IgE. Former studies have already shown the inflammatory potential of IgE aggregates injected into the skin of guinea pigs and rats. ${ }^{20}{ }^{21}$ In this study it was shown that the intra-articular injection of IgE aggregates causes mast cell degranulation with a lowering of the concentration of histamine in tissues and a decreased number of stainable mast cells from eight hours after aggregate injection. In contrast with Malone and Metcalfe ${ }^{10}$ we found no statistically significant difference in the histamine content one hour after the injection of $\operatorname{IgE}$ aggregates and no marked increase in the permeability of the synovial membrane could be shown using intravenously injected bovine serum albumin labelled with iodine-125 as a marker. In our study, the relatively small number of rats and the wide range of values in the permeability study could explain this difference.

In a rabbit model, where immune complexes containing IgG were injected intra-articularly, a pronounced leucocyte infiltration into the joints was found eight hours after injection, especially when small immune complexes formed in an excess of antigen were used. ${ }^{22} 23$ However, in our study mast cell triggering and moderate hyperplasia of the synovial lining layer were the main features and definite neutrophil or mononuclear cell infiltration was not consistently found. An explanation for the lack of neutrophil infiltration might be that aggregated IgE does not activate complement by the classical pathway and thus less chemotactic components (C3a, C5a, C567) are liberated.

In summary, this experimental arthritis model in rats provides further evidence for the arthritogenic potential of complexed IgE, especially in the initiation of arthritis by mast cell activation. In humans, where immune complexes containing IgE can be found intraarticularly and synovial mast cells are numerous, these events could be an initiating factor and/or an inflammatory amplification loop in the physiopathology of rheumatoid arthritis.

We thank Frank Rylant for technical assistance and Pharmacia for providing the histamine RIA 50 kits. This work was supported in part by the Nationaal Fonds voor Wetenschappelijk Onderzoek (grant 9.0030.87).
1 Meretey K, Falus A, Erhardt C C, Maini R N. IgE and IgErheumatoid factors in circulating immune complexes in rheumatoid arthritis. Ann Rheum Dis 1982; 41: 405-8.

2 Meretey K, Falus A, Böhm V, Permin H, Wiik A. IgE class immune complexes in Felty's syndrome: characterisation of antibody activities in isolated complexes. Ann Rheum Dis antibody activities

3 De Clerck L S, Westedt M L, Cats A, et al. IgE deposition in normal skin of patients with rheumatoid arthritis in relation to clinical and laboratory findings. Ann Rheum Dis 1985 44: 772-7.

4 De Clerck L S, Struyf N J, Bridts C H, et al. Humoral immunity and composition of immune complexes in patients with rheumatoid arthritis with special reference to gE-containing immune complexes. Clin Exp Rheumatol 1989; 7: 485-92.

5 De Clerck L S, Struyf N J, Bridts $\mathrm{C} \mathrm{H}$, et al. IgE-containing immune complexes in synovial fluid of patients with rheumatoid arthritis. Clin Rheumatol. 1990; 9: 176-81.

6 De Clerck L S, Gigase P L, Bridts C H, Stevens W J. Neutrophil activation by IgE-containing circulating immune complexes of patients with connective tissue diseases. complexes of patients with connective

7 Rousseaux J, Bazin H. Rat immunoglobulins. Vet Immunol Immunopathol 1979; 1: 61-78.

8 Segal D M, Taurog J D, Metzger H. Dimeric immunoglobulin E serves as a unit signal for mast cell degranulation. Proc Natl Acad Sci USA 1977; 74: 2993-7.

9 Caulfield J P, Hein A, Dynesius-Trentham R, Trentham $D$ E. Morphologic demonstration of two stages in the development of type II collagen-induced arthritis. Lab Invest 1982; 46: 321-43.

10 Malone D G, Metcalfe D D. Demonstration and characterization of a transient arthritis in rats following sensitization of synovial mast cells with antigen-specific IgE and parenteral challenge with specific antigen. Arthritis Rheum parenteral challen

11 Dalldorf F G, Anderle S K, Brown R R, Schwab J H. Mast cell activation by group A streptococcal polysaccharide in the rat and its role in experimental arthritis. Am $\mathcal{F}$ Patho 1988; 132: 258-64

12 Caulfield J P, Hein A, Helfgott S M, Brahn E, DynesiusTrentham R A, Trentham D E. Intraarticular injection of arthritogenic factor causes mast cell degranulation, inflammation, fat necrosis and synovial hyperplasia. Lab Invest 1988; 59: 82-95.

13 Malone D G, Wilder R L. Participation of synovial mast cells in intermittent hydarthrosis. Arthritis Rheum 1989; 32: 357-8.

14 Crisp A J, Chapman C, Kirkham S E, Schiller A L, Krane $S$ M. Articular mastocytosis in rheumatoid arthritis. Arthritis Rheum 1984; 27: 845-51.

15 Godfrey H P, Ilardi C, Engber W, Graziano F M. Quantitation of human synovial mast cells in rheumatoid arthritis and other rheumatic diseases. Arthritis Rheum 1984; 27: 852-6.

16 Wasserman S I. The mast cell and synovial inflammation. Arthritis Rheum 1984; 27: 841-4.

17 Gruber B, Poznansky M, Boss E, Partin J, Gorevic P, Kaplan A P. Characterization and functional studies of rheumatoid synovial mast cells. Arthritis Rheum 1986; 29: 944-55.

18 Malone D G, Irani A M, Schwartz L B, Barrett K E, Metcalfe $D$ D. Mast cell numbers and histamine levels in synovial fluids from patients with diverse arthritides. Arthritis Rheum 1986; 29: 956-63.

19 Spiegelberg H L, Melewicz F M. Fc receptors specific for IgE on subpopulations of human lymphocytes and monocytes. Clin Immunol Immunopathol 1980; 15: 424-33.

20 Ishizaka T, Ishizaka $\mathrm{K}$, Bennich $\mathrm{H}$, et al. Biologic activities of aggregated immunoglobulin E. F Immunol 1970; 104: $854-62$.

21 Dessaint J P, Torpier G, Capron M, et al. Cytophilic binding of IgE to the macrophage. I. Binding characteristics of $\mathrm{IgE}$ of IgE to the macrophage. I. Binding characteristics of $\mathrm{IgE}$ on the surface of

22 Bjursten L M, Bagge U, Ahlstedt S. Joint inflammation in rabbits induced by preformed immune complexes. Int Arch Allergy Appl Immunol 1981; 64: 67-71.

23 Bjursten $L M$, Thomsen $P$, Ahlstedt S, Bagge $U$. The kinetics of leukocyte migration into rabbit knee joints elicited by preformed immune complexes with different in vitro characteristics. Immunology 1983; 49: 205-13. 